\author{
Ján KOPEC ${ }^{1}$, Laura LACHVAJDEROVÁ ${ }^{2}$ \\ Supervisor: Miriam PEKARČÍKOVÁ ${ }^{3}$
}

DOI: https://doi.org/10.53052/9788366249844.11

\title{
NOWOCZESNE PODEJŚCIE DO MODELOWANIA ZAKŁADÓW PRODUKCYJNYCH W KONCEPCJI PRZEMYSŁU 4.0
}

\begin{abstract}
Streszczenie: Celem artykułu jest wskazanie innowacji w świecie techniki, w postaci czwartej rewolucji przemysłowej. Ten artykuł dotyczy koncepcji Przemysłu 4.0 i jej podstawowych elementów. Ponadto praca zawiera opis kluczowych innowacji w koncepcji „Przemysł 4.0” oraz praktyczne wykorzystanie tych elementów w firmach. . Poza tym analizowano również poziom automatyzacji w firmach, czy to dużych, średnich czy małych. Na końcu znajduje się układ zakładu produkcyjnego z innowacyjnymi rozwiązaniami Przemysłu 4.0 i szczegółowymi projektami w środowisku produkcyjnym.
\end{abstract}

Słowa kluczowe: Przemysł 4.0, Internet Rzeczy, Big data, Cloud computing, Systemy cyberfizyczne, Automatyka, Technologie informacyjno-komunikacyjne.

\section{MODERN APPROACHES TO MODELING PRODUCTION FACTORIES IN THE CONCEPT OF INDUSTRY 4.0}

Summary: The purpose of this article is to point out the innovations in the world of technology, in the form of the fourth Industrial Revolution. This article deals with Industry 4.0 concept and its fundamental elements. Besides, the work includes the description of key innovations in the "Industry 4.0" concept and the practical use of these elements in companies. Other than that, the publication also focuses on the level of automatization in companies i.e. large, middle, or small companies. In the end, there is a production facility layout with innovative Industry 4.0 solutions and the detailed designs in a production environment.

Keywords: Industry 4.0, Internet of Things, Big data, Cloud computing, Cyber-physical systems, Automation, Information and communication technology.

\footnotetext{
${ }^{1}$ Technical University of Kosice, Faculty of Mechanical Engineering, Department of Industrial and Digital Engineering; jan.kopec@tuke.sk

2 Technical University of Kosice, Faculty of Mechanical Engineering

${ }^{3}$ Technical University of Kosice, Faculty of Mechanical Engineering, miriam.pekarcikova@tuke.sk
} 


\section{Introduction}

Today, the number of technological improvements is growing every day, and the main challenge for businesses is the digital revolution. Communication of machines with each other is ensured using the Internet network. The "Industry 4.0" concept is the future for the industry. The basic principle is in the processing of a huge amount of information and the use of knowledge about materials, machines, and technologies. The advantage of using the "Industry 4.0" concept is the reduction of production times and ensures efficient, cleaner, and, most importantly, less expensive production. The concept of Industry 4.0 brings many benefits to industry, such as better products, reduced material consumption because the use of robots will reduce the error rate, increase production and thus increase production profits. Communication between machines and robots reduces the workload of employees, as harmful and strenuous work will be performed by machines and robots. The "Industry 4.0" concept also simplifies working with data. Adaptation and production flexibility will be taken to a higher level thanks to automation. The fourth industrial revolution is widely used, but it can be used most in the automotive industry, but also the engineering, electrical and chemical industries. In today's world, market uncertainty is growing, product life cycles are shortening, leading to customer dissatisfaction. The fourth industrial revolution will extend the life of products through intelligent production and the use of higher quality materials $[2,5,10]$.

\section{Characteristics of the Industry 4.0 concept}

Industry 4.0 describes several advanced technological changes in the volume of production, the main goal of which is to maintain the competitiveness of the company, as well as the industry. Industry 4.0 describes the functional involvement and organization of production processes based on mutual communication between machines, tools, and company employees. The basic goal is to create a "SMART FACTORY", where computer systems will control the production process as well as monitor physical processes, create a virtual model of the product, and autonomous management of the production organization. This concept is based on increasing the informatization of manufacturing industries, where physical objects are seamlessly integrated into the information network. Production systems are directly connected to business processes, which are processed at the time of receiving the order. The concept of Industry 4.0 depends on the effective use of CPS (cyber-physical) systems, which are aimed at creating intelligent production components, intelligent objects, and new production processes. In the future, companies will have to respond as effectively as possible to rapid development, flexible production in a complex environment. An essential part of the proper functioning of the company is also CPPS (Cyber-physical production systems), the connection of ICT (information and communication technologies), IoT (Internet of Things) ) and IoS (Internet of Services) [1,3,9]. 


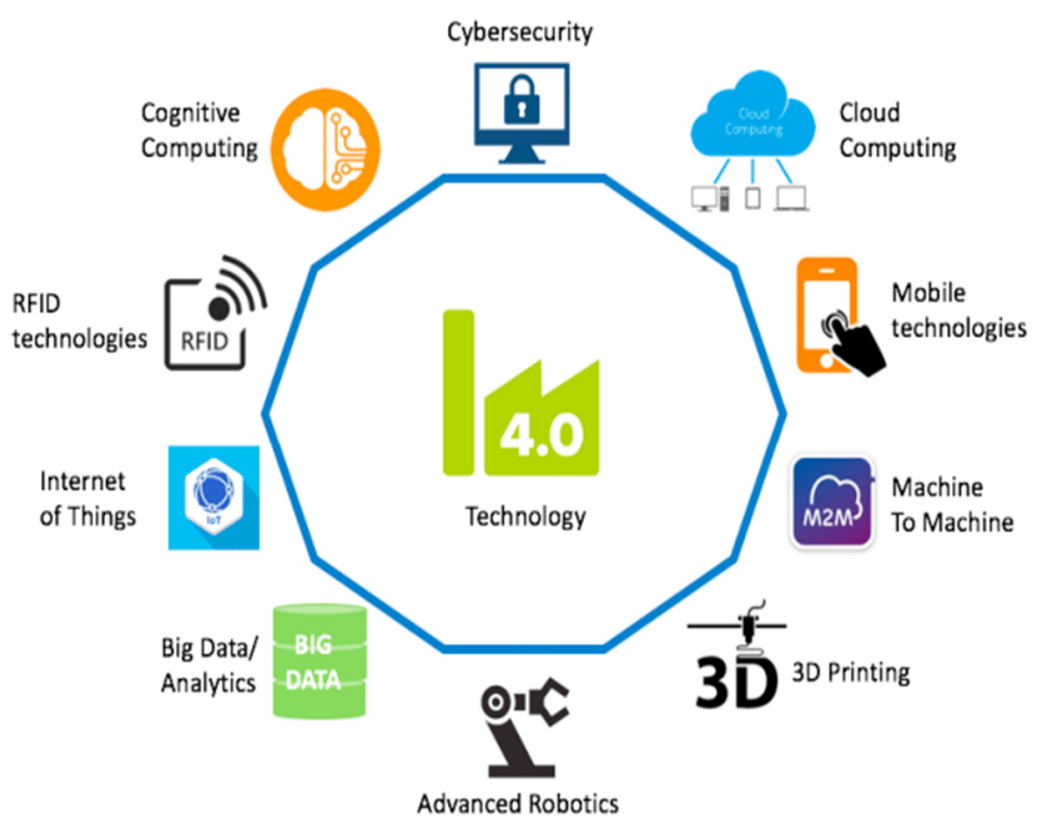

Figure 1. Technological pillars [5]

\subsection{Internet of Things}

The Internet of Things is a space located between networks in which information about objects is inserted using sensors, drivers, or other digital devices. The fundamental role of things is to connect and connect information so that it can be collected and data can be exchanged. The Internet of Things is capable of the very advanced interconnection of physical objects systems and services. Internet stuff ensures efficient communication between objects and data sharing. One of the most important technologies used in the Internet of Things is automatic identification technology, which is used to produce intelligent objects [11].

\subsection{Cyber-physical system}

The cyber-physical system (CPS) is a mechanism by which objects and software are closely interconnected and allows for mutual communication and the exchange of information. CPS includes several methods, such as cybernetics, engineering, and mechatronics, manufacturing systems, and informatics. One of the important techniques and methods is embedded systems, which allow a very interconnected relationship between physical objects and computational elements. The CPS system, unlike other systems, contains network interactions that are designed with the physical input and output used with their cybernetic uses, such as control algorithms and computing capacities. The number of sensors plays a very important role in CPS. The more sensors there are, the more we can gather information about a given object. In CPS, several sensor elements are used to provide different purposes, e.g. touch screens, light sensors, and force transducers [6]. 


\subsection{Cloud Computing}

Cloud Computing is a software component that provides users with computing services using visualized Internet resources. It helps manufacturing companies cope with today's rapidly changing technologies. Automation is increasingly being used in manufacturing, and cloud computing is a way for businesses to adapt to market conditions over time without losing data. Cloud technology has a very wide range of uses and variants of calculation, storage, and networking. The platforms can connect automation, robotics, and the Internet of Things, which help the company to innovate growth. The intelligence of stored data using cloud computing brings valuable knowledge about the operation of the company, which will better manage their activities in this modern age. It will increase the competitiveness of the company, which will increase profits. As a result, if the information is in one place, no network branching is required and costs are reduced [7].

\subsection{Big Data}

With the increasing pressure of today's digital age, information has become more accessible. Big data comes in various forms from devices such as sensors, networking, transactional applications, web media. Big data technologies analyze and process large amounts of data and information, multimedia interface machines such as touch screens and gesture control applications. These technologies will help employees take communication to a whole new level and the ability to interact in production. Using Big data technology, a data environment with a large amount of information was created. Although sensors, for example, have greatly simplified data acquisition and collection, they must also be properly processed to provide useful data and be used correctly. In the Big data sector, the information is contained in such an amount that it is almost impossible for ordinary software to identify, process, and use the information. Therefore, more advanced software is used that can identify hidden patterns, unknown correlations, market trends, and other useful business information. In most industries, it is possible to analyze customer relationship management data and the ability to focus on their requirements and thus achieve their satisfaction [4].

\subsection{ICT}

ICT technologies are part of an information system that ensures the interconnection of telecommunications as well as other technologies that can manipulate, store and transmit data in the form of information. Many technologies are associated with the concept of ICT, such as audiovisual systems and wireless systems. The focus is on data transmission using various media, whether using wired or wireless communication, where correct and fast information processing is required. ICT technologies have a significant impact on the organization of the company, which means that if the company has better information and communication technologies for its employees, there is also increased visibility and control over the production process. In terms of competitiveness, the use of modern ICT technologies is a great benefit, as they allow a quick response to market change and compliance with customer conditions. In modern times, almost all devices have access to the network, so ICT technologies have become very important because they provide fast design, 
interconnection delivery and production, simulation, modeling, and virtual production [12].

\section{Practical use of the Industry 4.0 concept for the creation of SMART FACTORIES}

In this section, I will focus on the elements of the plants of the future typical of the Industry 4.0 concept. It is a presentation of innovative industrial solutions, which are especially suitable for small and medium series production. Some solutions are already part of production facilities, some proposed solutions are concepts of the future. Automation is the future for businesses, whether it is a large enterprise, a medium-sized enterprise, or a small enterprise. For all companies, automation in conjunction with the Industry 4.0 concept brings significant resource savings. It is important that the elements of automation significantly facilitate the work of people who will only perform control activities in an automated company. The advantage of business automation as well as the "Industry 4.0" concept is the focus on precise customer requirements. On the other hand, for companies that introduce elements of automation into production, the acquisition costs may be too high, but the return on financial resources invested in automation over several years is assumed.

At the same time, the interconnection of progressive production technologies, such as water jet cutting and laser cutting brings high production accuracy and contributes to increasing the quality of products in the company. In water jet cutting, the advantage over other progressive technologies is the zero heat affected area.

Fig. 3 shows a workplace for pressing sheet metal products. This workplace is fully automated and uses robots of the ES165D type (Fig.2 (a)), which ensure smooth, fast, and, most importantly, accurate production. The great advantages of these robots are low procurement costs and low maintenance and operation costs.

The MH50 robots (Fig. 2 (b)), which are in the middle of an operation, have the task of adding RFID sensors to the moldings so that the rest of the working robots can collect and accurately record product information and data. I either created the machines to simulate the production environment using the 3D modeling program SolidWorks. There is also a machine library in the Inventor section and the Inventor Factory subroutine. With this add-on, it is possible to create a digital environment. The production process is as follows. Thanks to autonomous forklift trucks, sheet metal material is delivered to the workplace to the rear, to the machines. The excerpt exits the machine on a conveyor belt and then moves to the robots, which assign it an RFID chip. The robots also function to pick up the waste generated during processing and move it to the waste bins. The waste is further recycled and thus shifted back to production in the form of input material [8]. 


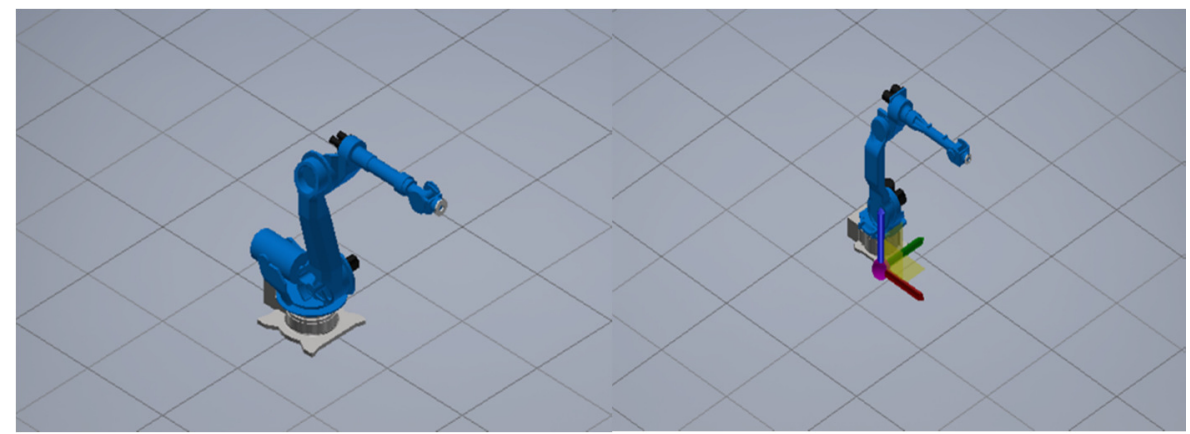

Figure 2. (a) ES165D (b) MH50

Autonomous robots are equipped with cameras that help them read and recognize the RFID sensors of the products. At the end of the belt conveyor are robots of the ES165SD type, which directly place the finished products on pallets. If the last machines detect that the pallet is full, they issue a signal by which the control center issues a command to stop pressing. RFID sensors carry information about the product throughout its processing.

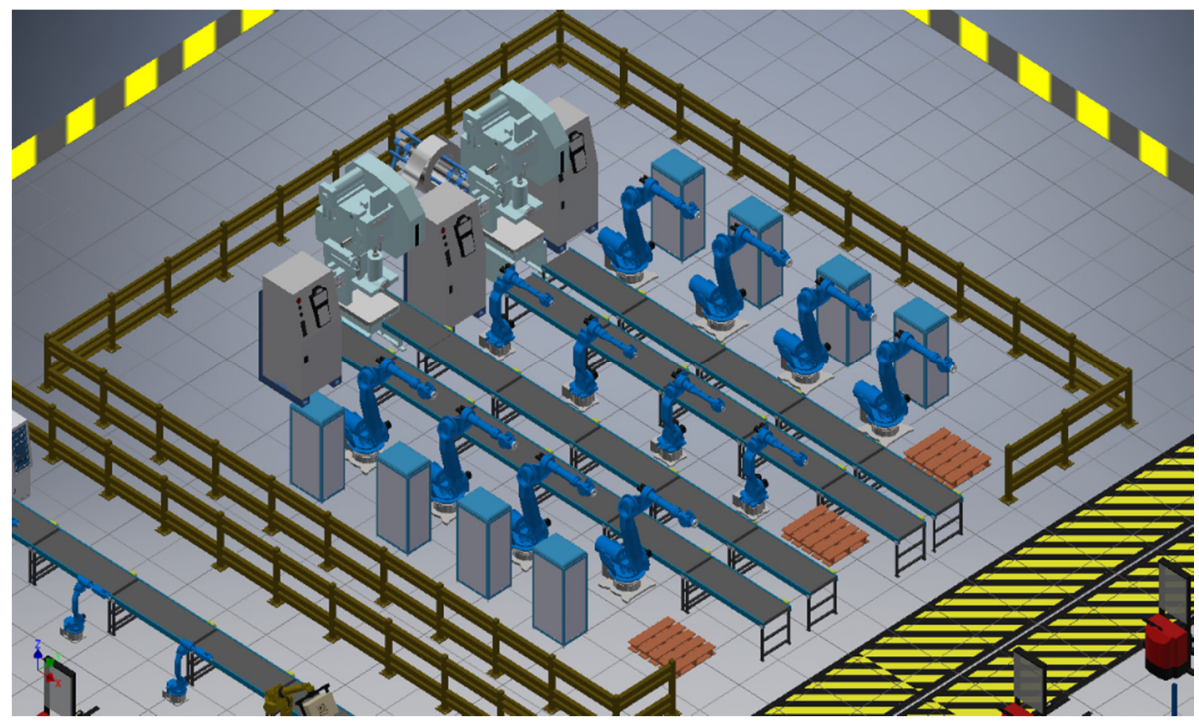

Figure 3. Automated workplace for pressing products

Another fully automated workplace in operation is designed for cutting sheet metal parts. Automated cutters are used (Fig.4). Their advantage is the accuracy of the final products and simplicity of production. The processing process on the automatic cutter is similar to the first workplace. Automatic trolleys transport the semi-finished product from the initial work to the automatic cutter, where the dimensions are cut to the finished form. 


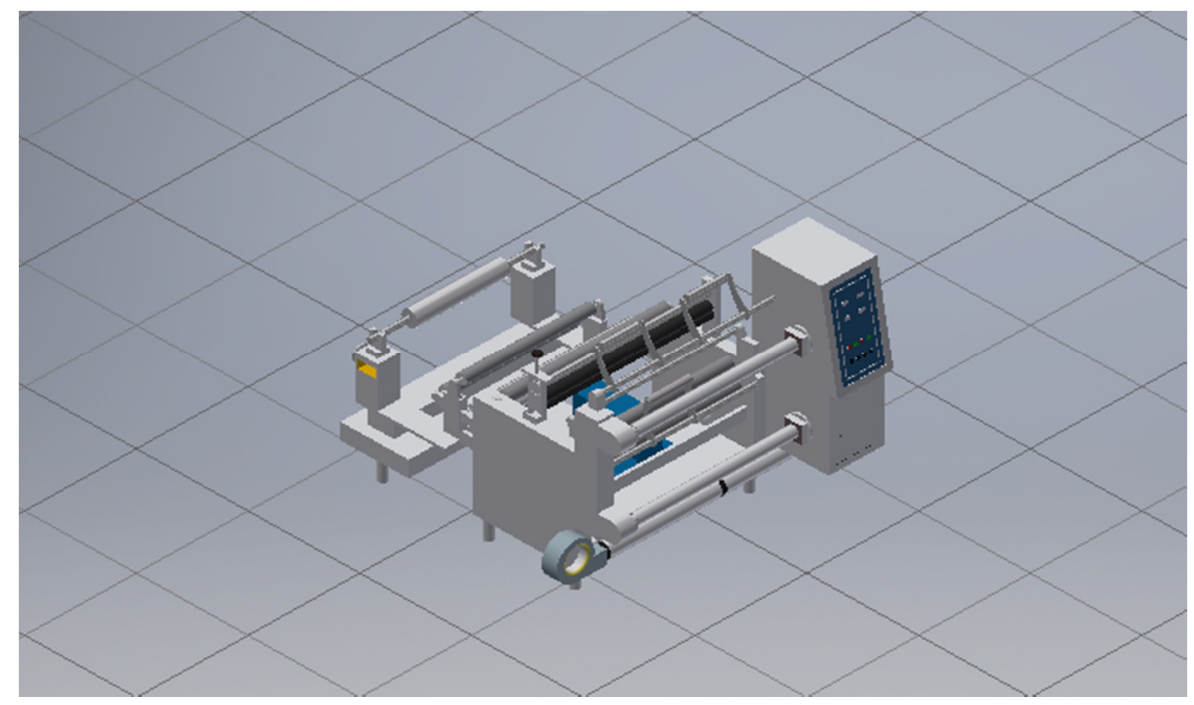

Figure 4. Automatic cutter

Robots of the RX 160HD_PRESERIAL-HB type are located on both sides of the cutters, which ensure the insertion of semi-finished products into automated cutters. These robots, like other robots in the whole operation, are equipped with cameras for reading RFID chips, so from the very beginning, the whole workplace has information on which semi-finished product is currently in production and how to handle it. Fig.5 is an automated workplace designed for cutting semi-finished products.

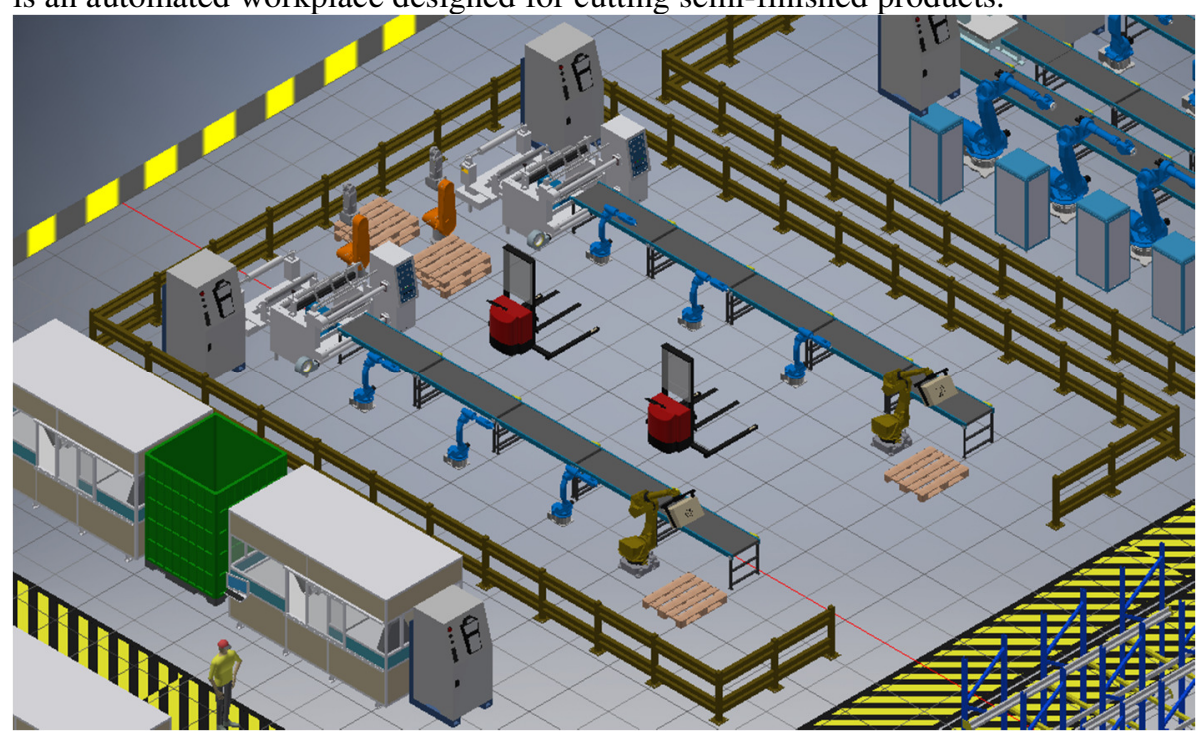

Figure 5. Automated workplace for cutting semi-finished products

At the end of the production line, there are robots of the Roboter KB Package, which have the task of inserting finished products into boxes and storing them on pallets. Again, as at the previous workplace, as soon as the robot detects that the pallet is full 
using a camera and information from the data center, it emits a signal that calls forklifts. These will again secure empty pallets so that production can continue.

The production also includes a workplace for laser and water jet cutting. This workplace is automated, the supply of sheet metal and the removal of finished products is ensured by robots and forklifts. Workers who do not interfere in the production process but control the production parameters of the machines are present. FIG. 6 is a water jet cutting device. Water jet cutting is an efficient, environmentally friendly process and there are no heat-affected areas when machining sheet metal that could change the structure of the product. The disadvantage of water jet cutting is the cost of the abrasive and also the inaccurate machining of the rough boards.

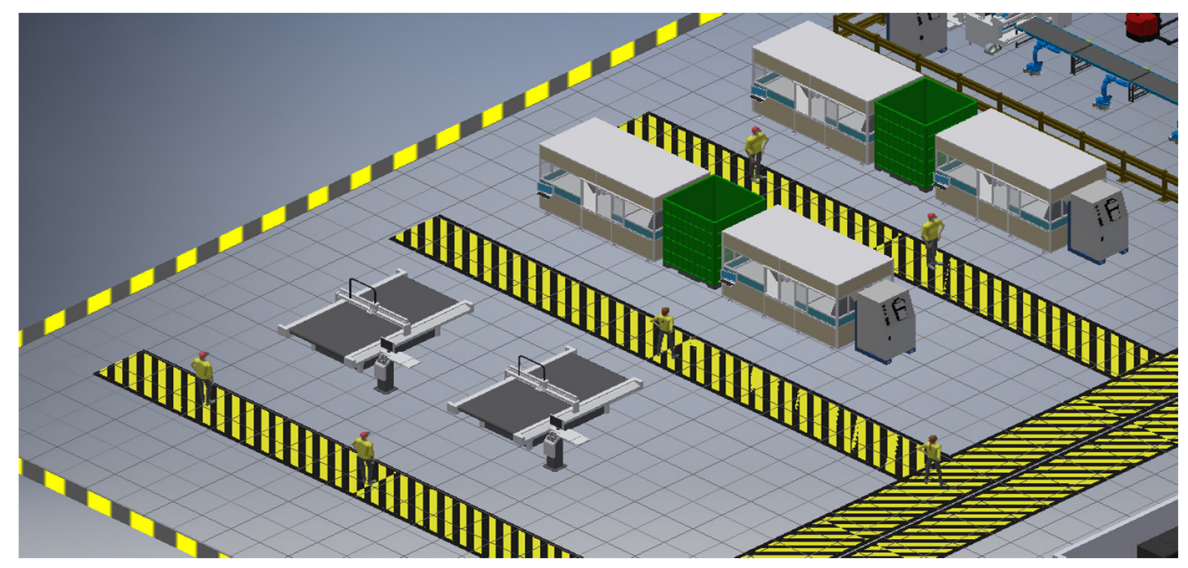

Figure 6. Automated workplace for water jet and laser cutting

Fig.7 shows an automated production hall using the "Industry 4.0" concept and automation elements. This modernized workplace serves as a model for presenting how companies could be modernized using the Industry 4.0 concept. Workplaces are completely or partially autonomous and so a minimum of workers is needed. However, the workers will not lose their jobs but will be qualified as programmers and designers. The data workplace is used for data collection.

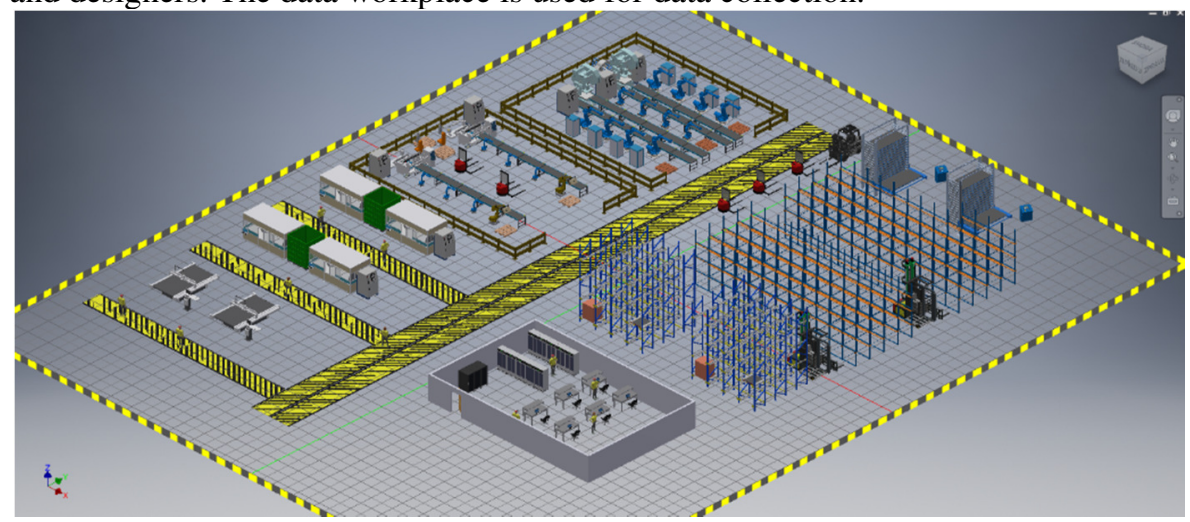

Figure 7. Automated production 


\section{The benefits of the Industry 4.0 concept}

The third industrial revolution made extensive use of electronics and information technology to expand automation. With the growing number of technologies and intelligent products and machines, the fourth industrial revolution began to take shape. The main goal of the Fourth Industrial Revolution is the development of an intelligent plant that is versatile, respecting the principles of ergonomics to ensure a safe workplace for employees [13].

Another significant advantage of the fourth industrial revolution is the focus on customer needs and requirements. To achieve an optimal focus on customer needs, the intelligent factory uses the latest technological and technical knowledge, automation technology, and mutually beneficial involvement of human factors.

Customer value needs to be created so that this process also creates benefits for the company. It is a new approach to the organization and management of production. Intelligent factories make it possible to produce mass-produced products according to individual customer requirements and to maintain a ratio of low price and high quality. For medium and small businesses, it offers digital and intelligent manufacturing processes, great opportunities to bring products to market, and ensures the company's competitiveness.

Smart factories will take full advantage of the cooperation of robots and humans. Machines are not expected to completely replace human labor. The production process will be controlled and serviced by robots and employees will perform inspections using appropriate equipment.

\section{Conclusion}

It is clear from my work that the concept of "Industry 4.0 " is of great benefit to the industry today. The introduction of elements of automation and digitization of the company brings financial benefits and increases the quality of products or services.

Of course, it is necessary to consider the correct use of key innovations of the "Industry 4.0" concept about the volume of production. Machine communication with each other is increasingly used in industry. Using the "Industry 4.0" concept will eliminate the hard and life-threatening work that people have had to do. Now such work will be done by machines.

\section{Acknowledgments}

This article was created by the implementation of the grant project VEGA 1/0508/22. 


\section{REFERENCES}

1. KOVÁČ, Jozef, Vladimír, RUDY a Juraj, KOVÁČ. Automatizácia výroby. Košice: Edícia vedeckej a odbornej literatúry, 2016. ISBN 978-80-553-23114.

2. TOMEK, Gustav a Věra, VÁVROVÁ. Průmysl 4.0, aneb, Nikdo sám nevyhraje. Průhonice: Professional Publishing, 2017. ISBN 978-80-906594-4-5.

3. MAŘÍK, Vladimír. Průmysl 4.0: výzva pro Českou republiku. Praha: Management Press, 2016. ISBN 978-80-7261-440-0.

4. BARTODZIEJ, Christoph Jan. The Concept Industry 4.0: An Empirical Analysis of Technologies and Applications in Production Logistics. Wiesbaden, Germany: Springer Gabler, 2017. ISBN 978-3-658-16502-4.

5. European Parliament Committees: Industry 4.0.[online]. Belgicko:2016.

Dostupné na internete:

http://www.europarl.europa.eu/committees/en/supporting-analysessearch.html.

6. SGT UNIVERSITY: Cloud Computing - An Emerging Technology [online]. USA:2018. Dostupné na internete: https://sgtuniversity.ac.in/cloud-computingan-emerging-technology/.

7. ELSEVIER: Intelligent Manufacturing in the Context of Industry 4.0.[online].Č́na:2017. Dostupné na internete: https://www.journals.elsevier.com/engineering.

8. ATP Journal: Ako začat's robotickou automatizáciou [online]. Dostupné na internete: https://www.atpjournal.sk/rubriky/prehladove-clanky/ako-zacat-srobotickou-automatizaciou.html?page_id=25388.

9. LogForum: DEVELOPING SMART SERVICES BY INTERNET OF THINGS IN MANUFACTURING BUSSINESS [online]. Fínsko:2018 [cit.2018-04-26]. Dostupné na internete: http://www.logforum.net.

10. DREAMSTIME: Industrial internet of things/ industry 4.0 concept [online]. [cit.2018-05-14]. Dostupné na internete: https://www.dreamstime.com/stockillustration-industrial-internet-things-industry-concept-as-illustrationimage59048635.

11. European Parliament Committees: Industry 4.0.[online]. Belgicko:2016 [cit.2018-04-12]. Dostupné na internete: http://www.europarl.europa.eu/committees/en/supporting-analysessearch.html.

12. ACCENTURE: Intelligent Automation.[online]. EN:2016 [cit.2018-05-9]. Dostupné na internete: https://www.slideshare.net/accenture/intelligentautomation-tech-vision-2016-trend-1-57642103.

13. STATISTA: Industries impacted by cyber-attacks worldwide as of September 2017 [online]. [cit.2018-05-14]. Dostupné na internete: https://www.statista.com/statistics/784590/cyber-attacks-on-industriesworldwide-2017>. 